\title{
Aspiration of a small bowel video capsule: a rare complication
}

\author{
Thomas Skouras, David Sawbridge, Alan Steel, Paul Collins
}

Gastroenterology, Royal Liverpool and Broadgreen University Hospitals NHS Trust, Liverpool, UK

\section{Correspondence to} Dr Thomas Skouras, skouras.thomas@yahoo.com

Accepted 12 April 2018

\section{DESCRIPTION}

Video capsule endoscopy (VCE) is a non-invasive tool for the direct visualisation of the small bowel mucosa with a reported complication rate of $1 \%-3 \% .{ }^{12}$ Capsule retention is the most common complication, accounting for $1.5 \%-2 \%{ }^{1}$

We present the case of a 72-year-old man with a medical history of inflammatory bowel disease, previous small bowel perforation and ileostomy, undergoing investigation for a high output stoma. Comorbidities included type 2 diabetes.

He had no history of dysphagia and reported no swallowing problems.

The patient underwent VCE after passing a patency capsule of identical dimensions, which exited the stoma 13 hours after ingestion. Following ingestion of the capsule (PillCam SB2, Given Imaging, Yokneam, Israel), the images received on the real-time viewer suggested initial location of the capsule in the oropharynx (see figure 1). Reinspection after 30 min suggested persistent pharyngeal retention. The capsule was located in the oropharynx via gastroscopy and placed endoscopically in the duodenum. This endoscopy demonstrated a structurally normal oesophagus without evidence of tracheoesophageal fistula, nor any stenosis of the upper gastrointestinal tract.

On review of the capsule images, it was apparent that the capsule had been aspirated to the level of the tracheal bifurcation (see figure 2) before its passage back into the oropharynx.

The patient remained asymptomatic throughout, reporting no problems swallowing the capsule.

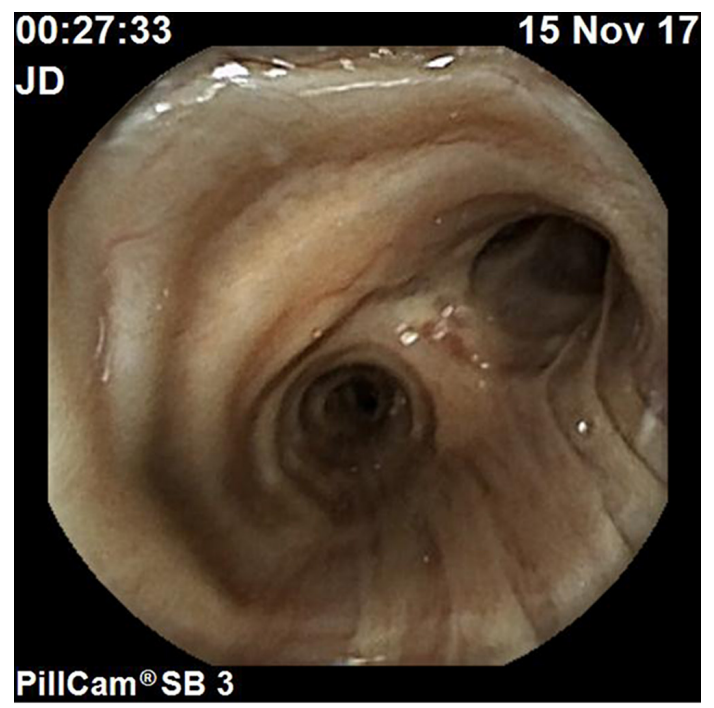

Figure 1 Vocal cords.

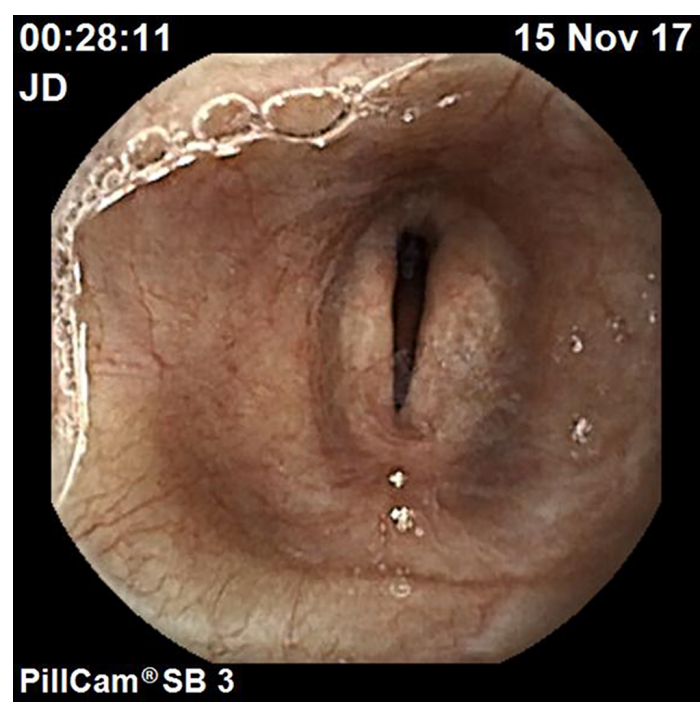

Figure 2 Carina of the trachea.

Capsule aspiration into the lungs is very rare. In our institution, we have performed 1647 VCEs to date, and this is the first occurrence of capsule aspiration. Thirty-seven cases of aspiration of a small bowel capsule have been reported in the literature with an estimated overall aspiration rate of $0.1 \%{ }^{1}$ The pathophysiology of the process is unknown in those without diagnosed neuromuscular dysfunction. Fifteen of the 37 patients reviewed were asymptomatic of aspiration. Dysphagia was uncommon (4 of 37), and all but two cases occurred in elderly men. Half of the reported cases required an intervention, such as bronchoscopy, to retrieve the device. The remaining patients either coughed the capsule out or eventually swallowed it into their stomach. In our case, the capsule was retrieved from the oropharynx before either could occur.

No directly linked fatalities have been noted in the literature, although one patient required antibiotics for an associated pneumonia. ${ }^{1}$ Our patient had no complications following this event.

High-risk individuals for VCE aspiration include those with compromised swallow due to neuromuscular or structural impairments of the oropharynx and oesophagus. ${ }^{3}$ Screening is based on clinical history and appropriate investigations. Alternative investigative modalities or endoscopic postpyloric placement should be considered. Appropriate consent procedures, including discussion of aspiration risk, assiduous identification of high-risk individuals and routine monitoring of capsule position in real-time, mitigate this risk. Nonetheless, this complication cannot always be excluded. 


\section{Learning points}

- Careful screening for those at risk of capsule aspiration should be performed at the time of referral and endoscopic postpyloric placement used where indicated.

- Routine inclusion of aspiration risk (approximately $0.1 \%$ ) within the consent process.

- Routine monitoring of the postingestion position should be undertaken to confirm passage into the small bowel.

Contributors For the drafting of the manuscript, the following authors contributed: TS and DS: Literature review and drafting of the manuscript. AS: Planning and design of the manuscript. PC: Interpretation of findings and final revision of manuscript. All authors are in agreement to be accountable for all aspects of the work and in ensuring that questions related to the accuracy or integrity of any part of the work are appropriately investigated and resolved.
Funding The authors have not declared a specific grant for this research from any funding agency in the public, commercial or not-for-profit sectors.

Competing interests None declared.

Patient consent Obtained.

Provenance and peer review Not commissioned; externally peer reviewed.

(C) BMJ Publishing Group Ltd (unless otherwise stated in the text of the article) 2018. All rights reserved. No commercial use is permitted unless otherwise expressly granted.

\section{REFERENCES}

1 Yung DE, Plevris JN, Koulaouzidis A. Short article: Aspiration of capsule endoscopes: a comprehensive review of the existing literature. Eur J Gastroenterol Hepatol 2017:29:428-34

2 Koulaouzidis A, Rondonotti E, Karargyris A. Small-bowel capsule endoscopy: a ten-point contemporary review. World J Gastroenterol 2013;19:3726-46.

3 Gómez V, Cheesman AR, Heckman MG, et al. Safety of capsule endoscopy in the octogenarian as compared with younger patients. Gastrointest Endosc 2013;78:744-9.

Copyright 2018 BMJ Publishing Group. All rights reserved. For permission to reuse any of this content visit

http://group.bmj.com/group/rights-licensing/permissions.

BMJ Case Report Fellows may re-use this article for personal use and teaching without any further permission.

Become a Fellow of BMJ Case Reports today and you can:

- Submit as many cases as you like

- Enjoy fast sympathetic peer review and rapid publication of accepted articles

- Access all the published articles

- Re-use any of the published material for personal use and teaching without further permission

For information on Institutional Fellowships contact consortiasales@bmjgroup.com

Visit casereports.bmj.com for more articles like this and to become a Fellow 